\title{
Kebijakan Netralitas Politik Pegawai Negeri Sipil dalam Pemilukada (Studi di Jawa Tengah)*
}

\author{
Sri Hartini ${ }^{30}$, Setiajeng Kadarsih ${ }^{31}$, dan Tedi Sudrajat ${ }^{32}$
}

\begin{abstract}
Abstrak
Penelitian tentang kebijakan netralitas politik Pegawai Negeri Sipil (PNS) dalam pemilukada ini dimaksudkan untuk mengevaluasi kebijakan dalam rangka mengantisipasi keterlibatan PNS dalam aktivitas politik praktis maupun yang menunjang aktivitas politik praktis, khususnya dalam pelaksanaan pemilukada di wilayah Jawa Tengah. Pendekatan yang digunakan dalam penelitian ini bukan hanya pendekatan doktrinal, tetapi juga penelitian terhadap hukum sebagai law in action yang non-doktrinal. Subyek penelitiannya adalah KPU Provinsi Jawa Tengah, Bawaslu Provinsi Jawa Tengah, Panwaslu, KPUD dan BKD di Kabupaten Banyumas, Purbalingga, Semarang, Solo, dan Karanganyar. Berdasarkan hasil penelitian, diketahui bahwa sumber masalah dalam penerapan netralitas PNS adalah lemahnya fungsi koordinasi dan penerapan sanksi. Hal ini didasarkan pada permasalahan substansi yang bias dalam menempatkan netralitas PNS sebagai objek hukum. Hasilnya, terciptalah kebijakan yang sifatnya sektoral yang tidak dapat menuntaskan permasalahan, baik dari unsur kelembagaan, ketatalaksanaan, maupun penegakan hukumnya.
\end{abstract}

Kata Kunci: netralitas politik, Pegawai Negeri Sipil (PNS), pemilukada, partai politik, politik praktis.

\section{Policy on Political Neutrality of Civil Servants in Regional Election (A Study in Central Java)}

\begin{abstract}
This research on the political neutrality policy for civil servants in the regional election has the intention to evaluate the policy in order to anticipate the involvement of civil servants in political activities, especially in the Regional Election of Central Java. In this regard, the approach used by this study is not only doctrinal, but also the study of law in action as nondoctrinal. The subject of this research are KPU of Central Java Province, Bawaslu of Central
\end{abstract}

* Artikel ini merupakan intisari dari Penelitian Tahun Pertama Hibah Bersaing dengan judul yang sama, didanai melalui skim Penelitian Hibah Bersaing Desentralisasi Universitas Jenderal Soedirman Purwokerto Tahun 2014.

30 Dosen Fakultas Hukum Universitas Jenderal Soedirman Purwokerto, Jl. Prof. H.R. Boenyamin No. 708 Grendeng Purwokerto, hartini.wy@gmail.com, S.H. (Universitas Jenderal Soedirman), M.H. (Universitas Airlangga).

31 Dosen Fakultas Hukum Universitas Jenderal Soedirman Purwokerto, Jl. Prof. H.R. Boenyamin No.708 Grendeng Purwokerto, setiajengkadarsih@unsoed.ac.id, S.H. (Universitas Diponegoro), S.H. (Universitas Airlangga).

32 Dosen Fakultas Hukum Universitas Jenderal Soedirman Purwokerto, Jl. Prof. H.R. Boenyamin No.708 Grendeng Purwokerto, t_sudrajat@yahoo.com, S.H., M.H. (Universitas Jenderal Soedirman). 
Sri Hartini, Setiajeng Kadarsih, dan Tedi Sudrajat: Kebijakan Netralitas Politik Pegawai Negeri Sipil dalam Pemilukada (Studi di Jawa Tengah)

Java Province, Election Supervisory Committee, the Election Commission and BKD in Banyumas, Purbalingga, Semarang, Solo, and Karanganyar. The research found that the identified the source of the problem is the weak function of coordination and implementation of sanctions. The problem is due to the biased legal substance which confines the neutrality of civil servants as an object of law. It creates sectoral policies those are unable to resolve the problems from institutional, managerial, and law enforcement aspects.

Keywords: political neutrality, civil servants, regional head election, political party, low politics.

\section{A. Pendahuluan}

Dalam politik birokrasi, upaya pembenahan yang dilakukan oleh para pemimpin negara dunia ketiga dimaksudkan untuk menciptakan mekanisme politik yang memungkinkan maksimalisasi produktivitas dan minimalisasi konflik sosial. Dalam praktiknya, mekanisme politik yang dianggap mampu menjamin pencapaian tujuan tersebut umumnya adalah mekanisme yang tidak demokratis. ${ }^{1}$ Hal tersebut terjadi juga di Indonesia. Pemerintah menerapkan konsepsi netralitas melalui peraturan untuk membatasi aktivitas politik para birokrat publik. Pola pengaturan yang dianggap tidak demokratis ini didasarkan pada kekhawatiran pemerintah terhadap birokrasi yang dapat membentuk peta kognitif (cognitive maps) dalam pelaksanaan kerjanya. Peta kognitif merupakan dasar dari struktur mental seseorang yang mau menerima dan menginterpretasikan tanda-tanda dari luar dirinya yang dapat membentuk kepercayaan sehingga mampu membuat keputusan, mau melakukan atau tidak melakukan sesuatu hal. ${ }^{2}$ Peta kognitif seseorang muncul tatkala terdapat situasi/kondisi yang menguntungkan salah satu pihak, yang kemudian menimbulkan implikasi hukum melalui dasar kepentingan politis disertai dasar argumentasi yang mendukung kepentingannya.

Dalam peta kognitif Pegawai Negeri Sipil (PNS), terdapat korelasi antara kepentingan hukum dan politik. Dalam perspektif sosiologis, PNS sering kali dijadikan sebagai gejala sosial yang cenderung berorientasi pada kepentingan politik praktis. Posisi PNS dalam masyarakat masih dianggap sebagai priyayi yang terhormat dan diperhitungkan. PNS ditempatkan sebagai media yang strategis dalam memengaruhi dan merekrut massa. Kondisi semacam ini yang ditengarai sebagai titik rawan PNS

Mohtar Mas'oed, Politik, Birokrasi dan Pembangunan, Yogyakarta: Pustaka Pelajar, 2008, hlm. 81.

Miftah Thoha, Birokrasi dan Politik di Indonesia, Jakarta: Raja Grafindo Persada, 2007, hlm.79. 
Sri Hartini, Setiajeng Kadarsih, dan Tedi Sudrajat: Kebijakan Netralitas Politik Pegawai Negeri Sipil dalam Pemilukada (Studi di Jawa Tengah)

sehingga menjadi tidak netral, sarat kepentingan dan rentan pelanggaran.

Berdasarkan fakta sejarah, terdapat beberapa hal yang perlu dievaluasi terkait kerentanan status PNS dalam politik praktis yaitu: Pertama, banyaknya kasus dalam pemilihan umum kepala daerah yang menunjukkan keterlibatan PNS dalam menyukseskan salah satu pasangan calon kepala daerah didasarkan oleh adanya iming-iming promosi jabatan. Implikasinya adalah semakin buruknya kualitas pelayanan masyarakat serta semakin terpuruknya citra pemerintah karena pembangunan sistem kerja yang tidak profesional dan memihak serta menyampingkan asas netralitas. Kedua, masih adanya ketidakpastian hukum atas posisi politik PNS. Disatu sisi setiap warga diberikan hak politik secara luas, namun disisi lain, PNS sebagai pelayan publik dibatasi hak politiknya.

Berkenaan dengan kebijakan terhadap pembatasan hak politik bagi PNS, tulisan ini dimaksudkan untuk mengelaborasi tentang kebijakan terhadap netralitas PNS dalam pemilihan umum di Indonesia, khususnya dalam pemilukada. Penentuan kriteria dalam mengidentifikasi dan mengualifikasi jenis-jenis kegiatan politik yang disebut sebagai pelanggaran netralitas PNS akan dijelaskan melalui perspektif sejarah dan politik hukum. Adapun kriteria tersebut digunakan sebagai dasar analisis terhadap faktor-faktor yang cenderung memengaruhi pelanggaran netralitas PNS tersebut, khususnya pada pelaksanaan pemilukada di wilayah Jawa Tengah.

\section{B. Politik Hukum Pemerintah terhadap Netralitas PNS dalam Pemilihan Umum di Indonesia}

Pembatasan kekuasaan memiliki korelasi yang erat dengan upaya untuk membatasi perilaku dari penguasa. Setiap peraturan memiliki pembatasan terhadap keberlakuannya untuk dapat menegaskan aspek kepastian, keadilan, dan kegunaan hukum. Artinya, tidak ada satupun peraturan yang keberlakuannya sepanjang zaman dan memenuhi kebutuhan realitas sosial yang terus berubah, sehingga setiap perubahan pada hakikatnya merupakan konsekuensi logis bagi setiap keinginan untuk memenuhi tuntutan zaman. ${ }^{3}$

Dalam hubungan hukum antara negara dengan pegawai pemerintah, telah ditegaskan ketentuan tentang pembatasan perilaku pegawai yang bekerja dalam instansi negeri. Hubungan ini disebut dengan hubungan dinas publik. Inti dari hubungan dinas publik adalah kewajiban bagi pegawai yang bersangkutan untuk tunduk pada pengangkatan dalam beberapa macam jabatan tertentu yang mengakibatkan pegawai yang bersangkutan tidak menolak (menerima tanpa syarat) pengangkatannya dalam satu jabatan yang telah ditentukan oleh pemerintah.

3 Ellydar Chaidir, Sistem Pemerintahan Negara Republik Indonesia Pasca Perubahan Undang-Undang Dasar 1945, Yogyakarta: Total Media, 2008, hlm. 294. 
Sri Hartini, Setiajeng Kadarsih, dan Tedi Sudrajat: Kebijakan Netralitas Politik Pegawai Negeri Sipil dalam Pemilukada (Studi di Jawa Tengah)

Pemerintah sebaliknya berhak mengangkat seorang pegawai dalam jabatan tertentu tanpa adanya penyesuaian kehendak dari yang bersangkutan. ${ }^{4}$ Dalam penerapannya, hubungan dinas publik ini berkaitan dengan segi pengangkatan birokrasi pemerintah yang dikenal dengan teori Contract Sui Generis. Teori yang dikemukakan oleh Buysini menyatakan bahwa Contract Sui Generis mensyaratkan birokrat pemerintah harus setia dan taat selama berstatus sebagai pegawai negeri, meskipun dia setiap saat dapat mengundurkan diri. Dari pendapat Buys ini, dapat disimpulkan bahwa selama menjadi pegawai negeri, mereka tidak dapat melaksanakan hak-hak asasinya secara penuh. ${ }^{5}$ Apabila pegawai negeri akan melaksanakan hak-hak asasinya secara penuh, maka pemerintah dapat menyatakan yang bersangkutan bukanlah orang yang diperlukan bantuannya oleh pemerintah. Berkaitan dengan hal ini, Philipus M. Hadjon menyatakan bahwa kajian hukum administrasi lebih memandang hubungan hukum kepegawaian tersebut sebagai hubungan Openbare Dienstbetrekking (hubungan dinas publik) terhadap negara (pemerintah). Hubungan dinas publik yang melekat pada hubungan kepegawaian itu lebih merupakan hubungan sub-ordinatie antara bawahan dan atasan. ${ }^{6}$

Untuk memperjelas perjalanan politik hukum mengenai kedudukan dari birokrat pemerintah, dilakukan penelaahan terhadap periode kekuasaan di Indonesia yang terbagi dalam 5 masa, yaitu masa awal kemerdekaan (Tahun 1945-1949), masa demokrasi liberal sampai dengan masa demokrasi terpimpin atau orde lama (Tahun 1950-1965), masa orde baru (Tahun 1965-1998), Tahun 1998-2014, dan Tahun 2014sekarang.

\section{Politik Hukum Pemerintah pada Masa Awal Kemerdekaan (Tahun 1945 - 1950)}

Sebelum kemerdekaan, birokrat pemerintah dikenal sebagai pangreh praja yang kedudukannya selalu dimanfaatkan oleh pemerintahan kolonial untuk berhubungan dengan masyarakat lokal, sementara administrasi pemerintahan kolonial dijalankan melalui semacam Departemen Dalam Negeri yang disebut dengan Binenlandsch Bestuur (BB). Pangreh praja ini sebenarnya oleh pemerintahan kolonial disebut dengan Inlandsch Bestuur atau pemerintahan pribumi. Status pangreh praja lebih rendah dari BB tetapi sangat berkuasa apabila berhadapan dengan rakyatnya. ${ }^{7}$

Sejak tanggal 17 Agustus 1945, istilah pangreh praja kemudian diganti menjadi pamong praja dan kemudian diperluas menjadi pegawai negeri. Secara struktural, keberadaan pegawai negeri pada awal kemerdekaan hanya melanjutkan fungsi

\footnotetext{
S.F. Marbun dan Mahfud M. D., Pokok-Pokok Hukum Administrasi Negara, Yogyakarta: Liberty, 1987, hIm. 98-99. Ibid, hlm. 99-100.

Philipus M.Hadjon (et.al.), Pengantar Hukum Administrasi Indonesia, Yogyakarta: Gadjah Mada University Press, 2005, hlm. 214.

7 Afan Gaffar, Politik Indonesia Transisi Menuju Demokrasi, Yogyakarta: Pustaka Pelajar, 1999, hlm. 230.
} 
Sri Hartini, Setiajeng Kadarsih, dan Tedi Sudrajat: Kebijakan Netralitas Politik Pegawai Negeri Sipil dalam Pemilukada (Studi di Jawa Tengah)

birokrasi yang telah dibuat oleh pemerintahan Belanda, ${ }^{8}$ namun secara normatif kedudukan dari pegawai negeri tersebut telah berubah dengan dikeluarkannya Maklumat Pemerintah Republik Indonesia (RI) pada tahun 1945 yang memerintahkan agar para pegawai negeri tetap menduduki pos-pos yang telah ada.

Pada awal kemerdekaan, birokrasi tidak berjalan normal dan banyak pegawai negeri yang terpecah belah. Selama revolusi fisik, pemerintah mengalami kesulitan untuk menata administrasi kepegawaian dengan baik karena lembaga yang menangani administrasi kepegawaian belum terbentuk sepenuhnya. Kantor Urusan Pegawai (KUP) dibentuk berdasarkan Peraturan Pemerintah No. 11 Tahun 1948 tanggal 30 Mei 1948 yang berkedudukan di Yogyakarta. KUP khusus dibentuk untuk menangani pegawai Pemerintah Rl, sedangkan pegawai yang mengabdi pada pemerintah Hindia Belanda dikelola oleh Djawatan Umum Urusan Pegawai (DUUP) yang dibentuk berdasarkan Keputusan Gubernur Jenderal Hindia Belanda No. 13 Tahun 1948, berselang beberapa hari setelah lahirnya KUP. Dikarenakan masih dalam suasana revolusi, Pemerintah RI tidak melakukan perubahan terhadap organisasi birokrasi peninggalan Belanda kecuali menambahkan Komite Nasional dalam mekanisme pemerintahan di Daerah (KND). ${ }^{9}$

Berdasarkan penjabaran di atas, maka upaya pembatasan peran serta politik pada tahun 1945-1950 bagi PNS belum ada. Hal ini terjadi karena situasi yang belum stabil dan belum adanya pengaturan tentang partai politik. Pada saat itu, aspek politik yang muncul adalah kepentingan untuk melegitimasi kekuasaan wilayah Pemerintah RI dan Belanda dengan cara mempertahankan dan menambah pegawai di wilayah yang dikuasai.

\section{Politik Hukum Pemerintah pada Masa Demokrasi Liberal sampai dengan Demokrasi Terpimpin (Tahun 1950-1965)}

Berdasarkan perkembangannya, pembinaan PNS, baik pada masa demokrasi liberal maupun demokrasi terpimpin, belum mendapat perhatian yang khusus. Keadaan ini disebabkan oleh adanya permainan politik yang tidak wajar dari partai/golongan tertentu sehingga menimbulkan kekacauan yang berlarut-larut di bidang kepegawaian. Partai/golongan tertentu berusaha memengaruhi dan menarik PNS untuk menjadi anggotanya, karena PNS pada umumnya mempunyai jabatan atau kecakapan yang berpengaruh dalam masyarakat luas. ${ }^{10}$

Akibat tidak adanya pembinaan kepegawaian, sering timbul kecurigaan di antara pegawai yang berbeda partai/golongan namun berada dalam kantor yang sama.

8 Pada saat kemerdekaan telah terbentuk provinsi, kota (gemeente), gewest (karesidenan), kabupaten (afdelingen) dan seterusnya. Pegawai pemerintahan pada saat itu berjumlah 82.000 orang (termasuk anggota angkatan bersenjata Hindia Belanda (KNIL), Ibid.

9 Ibid.

10 Korpri DKI Jakarta, Korpri dan Perkembangannya, Jakarta: Korpri, 1988, hIm. 4. 
Sri Hartini, Setiajeng Kadarsih, dan Tedi Sudrajat: Kebijakan Netralitas Politik Pegawai Negeri Sipil dalam Pemilukada (Studi di Jawa Tengah)

Permasalahan yang timbul adalah para pegawai saling mencari kesalahan dan sulit bekerja sama. Akibat yang lebih parah adalah timbulnya hierarki disiplin dan loyalitas ganda, yaitu disatu pihak seorang pegawai harus tunduk kepada kepala unit kerja sebagai atasan resmi, tetapi di lain pihak ia harus tunduk pula kepada atasannya yang tidak resmi, yaitu pimpinan partai politik. ${ }^{11}$

Perjalanan politik masyarakat dan Bangsa Indonesia pada masa ini menunjukkan kecenderungan yang sangat kuat bahwa birokrat (PNS) merupakan instrumen politik yang sangat efektif untuk dibangun oleh sebuah rezim guna membesarkan dan mempertahankan kekuasaannya. Hal ini bukan suatu hal yang baru, karena pola-pola pemanfaatan birokrasi sebagai suatu instrumen politik rezim telah terjadi sejak masa pemerintahan kolonial. ${ }^{12}$ Saat itu, PNS terbagi ke dalam partai-partai politik. Hal ini terus berjalan hingga pada masa Demokrasi Terpimpin. Apabila terjadi konflik kepentingan, seringkali pegawai yang menjadi anggota partai politik lebih mengutamakan dan mementingkan kepentingan partai/golongannya.

Untuk mengantisipasi permasalahan tersebut, pada masa Demokrasi Terpimpin dikeluarkan Peraturan Presiden (Perpres) No. 2 Tahun 1959 tentang Larangan Keanggotaan Partai Politik bagi Pejabat Negara Warga Negara Republik Indonesia, yang pada hakikatnya membatasi kebebasan berserikat PNS dan pejabat negeri. Hal ini ditegaskan dalam Pasal 2 Perpres No. 2 Tahun 1959 yaitu bahwa pejabat-pejabat negeri sebagaimana termaksud pada Pasal 1 ayat $(1)^{13}$ dilarang menjadi anggota suatu partai politik. ${ }^{14}$ Konsekuensi dari pelanggaran aturan ini adalah pegawai tersebut diberhentikan dengan hormat dari jabatan-jabatan negeri/perusahaan dan sebagainya. Dalam perkembangannya, Perpres No. 2 Tahun 1959 ditindaklanjuti dan diperluas dengan Surat Edaran (SE) Presiden Republik Indonesia No. 2 Tahun 1959 tentang Larangan Keanggotaan Partai Politik bagi Pejabat Negari Jang Mendjalankan Kewadjiban Negara di Luar Djabatan Jang Dipangkunja. ${ }^{15}$

Menyimak materi muatan Perpres No. 2 Tahun 1959 maupun SE Presiden Republik Indonesia No. 2 Tahun 1959, maka dapat disimpulkan bahwa Perpres ini membatasi kebebasan berpendapat sebagaimana yang tercantum dalam ketentuan

11 YKPI, Peranan dan Tugas Pegawai Republik Indonesia dalam Pembangunan, Jakarta: YKPI, 1984, hlm. 23.

12 Afan Gaffar, Politik Indonesia Transisi Menuju Demokrasi..., Op.cit., hlm. 230.

13 Yang dimaksud dengan "Pejabat Negeri" dalam Peraturan ini adalah:

a. Pegawai Pemerintah Pusat yang digaji menurut atau berdasarkan golongan F dari P.G.P.N.-1955 dan Pegawai Pemerintah Daerah yang digaji sesuai dengan golongan F P.G.P.N.-1955 tersebut;

b. Semua anggota Angkatan Perang dan Kepolisian Negara;

c. Anggota Direksi/Pimpinan/Staf pada badan-badan usaha/yayasan-yayasan/perusahaanperusahaan/lembaga-lembaga, baik yang secara langsung, maupun tidak langsung, seluruhnya atau untuk sebagian dimiliki oleh negara.

14 Yang dimaksud dengan "Partai Politik" menurut Pasal 1 ayat (2) Perpres No. 2 Tahun 1959 adalah organisasiorganisasi yang memperjuangkan susunan dan/atau corak dan/atau haluan negara.

15 Afan Gaffar, Politik Indonesia Transisi Menuju Demokrasi ..., Op.cit., hlm. 8. 
Sri Hartini, Setiajeng Kadarsih, dan Tedi Sudrajat: Kebijakan Netralitas Politik Pegawai Negeri Sipil dalam Pemilukada (Studi di Jawa Tengah)

Pasal 28 UUD 1945. Perpres ini merupakan wujud upaya pemerintah dalam memulihkan keadaan PNS yang pada saat itu berlarut-larut berada dalam permainan politik. Secara umum, perubahan politik ke era Demokrasi Terpimpin (1959-1966) tidak menghasilkan perubahan mendasar dalam proses birokratisasi, kecuali perubahan peta kekuatan politik yang ditandai dengan tiga konteks yaitu: Pertama, peranan partai politik mulai termarginalkan sebagai aktor utama dalam sistem politik; Kedua, menonjolnya figur Presiden Soekarno sebagai patron kekuasaan; dan Ketiga, masuknya kekuatan militer secara resmi ke pentas politik, menempati banyak jabatan strategis pemerintahan dari pusat hingga daerah. Menurut Mahfud M.D., keadaan pada masa Demokrasi Terpimpin juga dipengaruhi oleh produk hukum saat itu. ${ }^{16}$ Presiden menghendaki adanya Demokrasi Terpimpin, sehingga produk hukum yang dikeluarkan saat itu juga memiliki karakteristik yang dapat mendukung kebijakan Presiden. Demokrasi Terpimpin merupakan perwujudan kehendak Presiden dalam rangka menempatkan dirinya sebagai pihak yang paling berkuasa di Indonesia. ${ }^{17}$

\section{Politik Hukum Pemerintah pada Masa Orde Baru (Tahun 1965-1998)}

Pada dasarnya, masa Orde Baru merupakan masa pelaksanaan Pancasila secara murni dan konsekuen. Pelaksanaan ini meliputi segala bidang kehidupan, termasuk juga bidang kepegawaian. Pemerintah mencoba untuk menerapkan praktik-praktik pemerintahan sesuai yang tercantum dalam UUD 1945. Pada masa Orde Baru, pemerintah menyadari bahwa PNS harus diberi kebebasan untuk berserikat dalam partai politik. Hal ini diselaraskan dengan bunyi Pasal 27 ayat (1) UUD 1945 yaitu bahwa segala warga negara bersamaan kedudukannya dalam hukum dan pemerintahan dan wajib menjunjung hukum dan pemerintahan itu dengan tidak ada kecualinya, serta Pasal 28 UUD 1945 yang menyatakan bahwa kemerdekaan berserikat dan berkumpul, mengeluarkan pikiran dengan lisan dan tulisan dan sebagainya ditetapkan dengan undang-undang.

Untuk mempertahankan upaya pemerintah tersebut, dikeluarkanlah kebijakan dalam bentuk Undang-Undang No. 2 Tahun 1970 tentang Pencabutan Perpres No. 2 Tahun 1959 tentang Larangan Keanggotaan Partai Politik bagi Pejabat Negeri Warga Negara Republik Indonesia. Dalam penjelasan undang-undang ini, dinyatakan bahwa:

“Berdasarkan Ketetapan Majelis Permusyawaratan Rakyat Sementara No. XIX/MPRS/1966, Perpres No. 2 Tahun 1959 ternyata tidak memenuhi tuntutan hati nurani rakyat dalam rangka usaha pengamanan Revolusi 17 Agustus 1945 dan Undang-Undang Dasar 1945, oleh karenanya perlu

16 Mahfud M. D., Pergulatan Politik dan Hukum di Indonesia, Yogyakarta: Gama Media, 1999, hlm. 59.

17 Afan Gaffar, Politik Indonesia Transisi Menuju Demokrasi ..., Op.cit., hlm. 29. 
dicabut. Sesuai dengan hasrat bangsa Indonesia untuk membina Negara Republik Indonesia yang bersifat demokratis dan yang hendak menyelenggarakan keadilan sosial dan perikemanusiaan, maka Negara Republik Indonesia memupuk dan menjamin kemerdekaan tiap-tiap warga negaranya untuk berserikat dan berkumpul, mengeluarkan pikiran dengan lisan dan tulisan dan sebagainya, sebagaimana ditegaskan dalam Pasal 28 Undang-Undang Dasar 1945. Dengan dicabutnya Perpres No. 2 Tahun 1959, berarti bahwa larangan bagi pejabat negeri untuk menjadi anggota partai politik seperti yang dimaksud dalam Perpres No. 2 Tahun 1959, dihapus. Terhadap jabatan-jabatan tertentu yang tidak dapat diadakan perangkapan dengan keanggotaan organisasi politik, diatur dalam Peraturan Pemerintah sesuai dengan Undang-Undang No. 18 Tahun 1961."

Sehubungan dengan dikeluarkannya Undang-Undang No. 2 Tahun 1970, pemerintah memberikan kebebasan bagi pejabat negeri dalam berpolitik. Tindak lanjut dari aturan tersebut adalah dikeluarkannya Perpres No. 26 Tahun 1970 tentang Keanggotaan PNS dalam Partai Politik dan Golongan Karya. Pengaturan yang substansial dari peraturan pemerintah tersebut terdapat dalam Pasal 2 yang memberikan izin bagi PNS untuk terlibat dalam partai politik. ${ }^{18}$ Secara implisit, dalam Pasal 2 tersebut dinyatakan bahwa PNS yang memegang jabatan tertentu tidak dapat menjadi anggota partai politik dan golongan karya. Adapun pejabat-pejabat yang berwenang memberikan izin apabila PNS akan menjadi pengurus partai politik diatur dalam Peraturan Pemerintah No. 20 Tahun 1975 tentang Wewenang Pengangkatan, Pemindahan dan Pemberhentian PNS (LN Tahun 1975 No. 26 TLN No. 3058).

Pengaturan hukum di atas dipertegas kembali melalui pengakuan terhadap PNS dalam partai politik berdasarkan Pasal 8 Undang-Undang No. 3 Tahun 1985 tentang Perubahan Atas Undang-Undang No. 3 Tahun 1975 tentang Partai Politik dan Golongan Karya yang menyatakan bahwa:

a. PNS dapat menjadi anggota partai politik atau golongan karya dengan sepengetahuan pejabat yang berwenang;

b. PNS yang memegang jabatan-jabatan tertentu tidak dapat menjadi anggota partai politik atau golongan karya, kecuali dengan izin tertulis dari pejabat yang berwenang.

Secara normatif, ketentuan tentang izin tertulis kepada pejabat yang berwenang dimaksudkan untuk memberikan kekuasaan kepada pejabat yang berwenang dalam hal penentuan sikap untuk memperbolehkan atau tidak memperbolehkan seorang

18 Menurut Pasal 1 angka 1 Undang-Undang No. 3 Tahun 1975 tentang Partai Politik dan Golongan Karya, dijelaskan bahwa zaman Orde Baru memiliki dua Partai Politik yaitu Partai Persatuan Pembangunan dan Partai Demokrasi Indonesia serta satu Golongan Karya, yang pada saat berlakunya undang-undang ini bernama Golongan Karya. 
Sri Hartini, Setiajeng Kadarsih, dan Tedi Sudrajat: Kebijakan Netralitas Politik Pegawai Negeri Sipil dalam Pemilukada (Studi di Jawa Tengah)

PNS berperan serta dalam partai politik. Penentuan sikap ini kemudian harus dapat dipertanggungjawabkan secara rasional berdasarkan kepentingan negara dan kapasitas dari PNS tersebut. Namun dalam kenyataannya, pertimbangan pejabat yang berwenang untuk memberi izin bagi PNS untuk menjadi anggota maupun pengurus partai politik berpotensi untuk dipolitisasi.

Berdasarkan penjabaran di atas, dapat disimpulkan bahwa pengaturan tentang PNS dalam proses politik pada zaman Orde Baru dipengaruhi oleh politik hukum pemerintah yang memiliki kecenderungan untuk mempertahankan kekuasaan. Hal ini didasarkan pada pola pikir pemerintah dalam struktur pemerintahan, yang titik berat kekuasaannya berada di tangan penguasa birokrasi pemerintah sehingga rakyat sebagai unsur utama demokrasi tidak mempunyai peran yang dapat mengontrol birokrasi pemerintah secara maksimal. Kekuasaan ini disalahgunakan oleh penguasa Orde Baru untuk menguasai struktur birokrasi pemerintahan dengan konsep monoloyalitas. Semua pejabat, termasuk pegawai dari berbagai lini mempunyai jabatan dan kewajiban rangkap yang memihak kepentingan golongan yang berkuasa. Keadaan seperti ini yang membuat sistem sentralisasi pemerintahan menjadi kuat. Konsep mono-loyalitas ini berdampak pada penataan kepegawaian atau sumber daya aparatur pemerintah. Dibentuknya organisasi tunggal Korps Pegawai Republik Indonesia (Korpri) menunjukkan bahwa tidak ada alternatif lain bagi semua pegawai pemerintah kecuali memihak kepada golongan politik yang memerintah. Penataan kepegawaian menjadi semakin jauh dari kompetensi yang seharusnya dimiliki oleh aparatur pemerintah yang menjalankan tugas untuk melayani rakyat.

\section{Politik Hukum Pemerintah pada Tahun 1998- 2014}

Akibat permainan politik yang dilakukan dalam Orde Baru terhadap pegawai negeri dalam partai politik, telah terjadi ketidakseimbangan dalam perolehan suara di setiap pemilu, yang kemudian memicu konflik dalam partai politik. Kabinet Reformasi Pemerintahan Habibie berupaya melakukan reformasi di segala bidang dalam rangka reformasi politik menuju kehidupan politik yang lebih demokratis. Upaya tersebut dilakukan guna menciptakan pemerintahan yang baik, berwibawa dan bersih, termasuk di dalamnya pandangan pemerintah untuk meninjau kembali kedudukan PNS dalam kehidupan partai politik.

Pada era ini, pemerintah mencantumkan netralitas PNS dalam Pasal 3 UndangUndang No. 43 Tahun 1999 tentang Perubahan Atas Undang-Undang Nomor 8 Tahun 1974 tentang Pokok-Pokok Kepegawaian yang berbunyi :

(1) Pegawai Negeri berkedudukan sebagai unsur aparatur negara yang bertugas untuk memberikan pelayanan kepada masyarakat secara profesional, jujur, adil, dan merata dalam penyelenggaraan tugas negara, pemerintahan, dan pembangunan; 
(2) Dalam kedudukan dan tugas sebagaimana dimaksud dalam ayat (1), Pegawai Negeri harus netral dari pengaruh semua golongan dan partai politik serta tidak diskriminatif dalam memberikan pelayanan kepada masyarakat;

(3) Untuk menjamin netralitas Pegawai Negeri sebagaimana dimaksud dalam ayat (2), Pegawai Negeri dilarang menjadi anggota dan/atau pengurus partai politik.

Penjabaran atas pembatasan peran serta PNS dalam proses politik pada era reformasi memberikan gambaran sebagai berikut: Pertama, birokrasi dipandang sebagai instrumen teknis (technical instrument); Kedua, birokrasi dipandang sebagai kekuatan yang independen dalam masyarakat, sepanjang birokrasi mempunyai kecenderungan yang melekat (inherent tendency) pada penerapan instrumen teknis tersebut; Ketiga, pengembangan dari sikap ini dikarenakan birokrat yang tidak mampu memisahkan perilaku mereka dari kepentingannya sebagai suatu kelompok yang partikular. Dengan demikian, birokrasi bisa keluar dari fungsi yang seharusnya karena anggotanya yang cenderung datang dari kelas sosial partikular tersebut. Birokrasi hanya terbatas pada upaya untuk mengatur sistem administrasi dan organisasi secara rasional. Oleh karena itu, syarat-syarat yang ditetapkan dalam birokrasi hanya akan melihat dalam organisasi itu sendiri (in world looking), bukannya melihat faktor-faktor di luar (out world looking) yang bisa memengaruhi sistem birokrasi. ${ }^{19}$

\section{Politik Hukum Pemerintah pada Tahun 2014-Sekarang}

Pada 19 Desember 2013, DPR mengesahkan Undang-Undang No. 5 Tahun 2014 tentang Aparatur Sipil Negara sebagai pengganti Undang-Undang No. 43 Tahun 1999 tentang Pokok-Pokok Kepegawaian. Undang-undang ini ditandatangani oleh Presiden Susilo Bambang Yudhoyono pada 15 Januari 2014. UU Aparatur Sipil Negara (UU ASN) menempatkan semangat kata profesional, profesionalisme, atau profesionalitas sebagai bagian penting dalam materi muatannya.

Salah satu bagian dalam UU ASN yang berhubungan dengan netralitas termaktub dalam Bab III mengenai Jenis, Status, dan Kedudukan. Berdasarkan Pasal 9 ayat (1), pegawai Aparatur Sipil Negara (ASN) melaksanakan kebijakan yang ditetapkan oleh pimpinan instansi pemerintah. Sementara itu, pada ayat (2) ditegaskan bahwa pegawai ASN harus bebas dari pengaruh dan intervensi semua golongan dan partai politik.

Secara umum dapat digambarkan bahwa saat ini terdapat ciri-ciri model netralitas politik birokrasi, yaitu: Korps ASN yang dinyatakan independen dari partai politik; birokrasi tidak berafiliasi politik; birokrasi berjarak dengan partai politik; birokrasi bersikap nondiskriminatif terhadap warga negara dan partai politik; peran Lembaga Swadaya Masyarakat (LSM) dan kelompok kepentingan yang leluasa dan masyarakat berpartisipasi secara otonom untuk membangun civil society. 


\section{Kriteria yang Digunakan dalam Mengidentifikasi dan Mengualifikasikan Jenis- jenis Kegiatan Politik sebagai Pelanggaran Netralitas PNS}

Hukum adalah seperangkat aturan atau norma yang memiliki kekuatan sanksi yang pelaksanaannya dapat dipaksakan oleh negara/aparat penyelenggara negara. Hukum berisi seperangkat aturan yang mengatur sebagian besar kehidupan manusia. Hukum diciptakan untuk melindungi nilai-nilai yang hidup dalam masyarakat. Nilai-nilai yang dimaksud adalah nilai-nilai penghormatan atas jiwa, tubuh, harta, kehormatan dan kemerdekaan. Kegiatan manusia amat banyak sehingga hukum itu sendiri sudah dipastikan tidak mampu untuk mengakomodasi atau melindungi dan mengatur seluruh kegiatan manusia tersebut. Menurut Max Weber, untuk berlakunya suatu hukum harus terdapat alat pemaksa dalam hukum karena alat pemaksa menentukan adanya hukum. ${ }^{20}$

Dalam konteks hukum dan politik, birokrasi pemerintah dijadikan sebagai suatu sistem sosial yang pada hakikatnya terdiri dari bermacam-macam proses. Di antara bermacam-macam proses tersebut, dapat dilihat gejala-gejala politik sebagai suatu kumpulan proses tersendiri yang berbeda dengan proses-proses lainnya. Dalam konsep politik ini, ditemukan istilah-istilah seperti proses, struktur dan fungsi. Proses adalah pola-pola (sosial dan politik) yang dibuat oleh manusia dalam mengatur hubungan antara satu sama lain. Pola-pola ini ada yang jelas terlihat tetapi ada pula yang tampak kurang jelas. Dalam suatu lembaga birokrasi, sekalipun sudah mempunyai kehidupan sendiri, sebenarnya tak lain dari proses-proses yang pola-pola ulangannya sudah mantap. Hal ini mencerminkan struktur tingkah laku antara manusia dengan lembaga yang ternormakan dalam suatu hukum. Oleh karena itu, hukum dan politik dalam birokrasi pemerintah selalu terkait antara satu dengan yang lainnya.

Interrelasi antara hukum, demokrasi dan politik terjelma dalam konsep netralitas bagi PNS. Berdasarkan hasil wawancara dengan Komisioner Badan Pengawas Pemilu (Bawaslu) Provinsi Jawa Tengah, dijelaskan bahwa:

"PNS merupakan salah satu elemen penting dalam proses kemajuan demokrasi saat ini. Sebagai salah satu elemen utama dalam kemajuan demokrasi suatu negara, PNS harus berorientasi terhadap pelayanan publik. Keterlibatan PNS dalam proses demokrasi telah terakomodasi melalui keterlibatan PNS untuk menggunakan hak pilihnya dalam penyelenggaraan pemilu. Penggunaan hak pilih PNS dalam penyelenggaraan pemilu merupakan partisipasi langsung PNS dalam menentukan arah kepemimpinan atau sirkulasi kepemimpinan. Konsepsi netralitas dan parameter netralitas bagi PNS dalam pemilu, khususnya dalam pemilukada

20 Soerjono Soekanto, Kesadaran Hukum dan Kepatuhan Hukum, Jakarta: Rajawali, 1982, hlm. 2. 
dapat dilihat dari kemandirian PNS untuk tidak terlibat langsung dalam politik praktis. PNS sebagai organ utama pelayanan publik harus lepas dari gonjang-ganjing kekuasaan politik daerah serta tidak memihak terhadap pasangan calon tertentu. Dengan demikian, konsepsi netralitas dan parameter netralitas bagi PNS dalam pemilukada diukur dari kebebasan serta kemandirian PNS dalam menentukan kebijakan hak politiknya tanpa dipengaruhi politisasi dalam jenjang karir PNS."

Komisioner Bawaslu Provinsi Jawa Tengah memiliki pandangan bahwa: "Kebijakan netralitas PNS dalam pemilukada sudah tepat untuk melindungi PNS dari kegaduhan politik di daerah". ${ }^{21}$ Pernyataan Komisioner Bawaslu tersebut senada dengan pendapat dari Kepala Badan Kepegawaian Daerah (BKD) Kota Semarang, Bambang Kono yang menyatakan bahwa: "Netralitas PNS diperlukan untuk menciptakan PNS yang profesional, menjadi abdi dan pelayan masyarakat, tidak bersikap diskriminatif atau memihak salah satu partai politik". ${ }^{22}$

Panwaslu Kabupaten Purbalingga memandang bahwa selama ini PNS kerap dijadikan lumbung suara untuk memenangkan calon tertentu. Oleh karena itu, salah satu objek pengawasan penyelenggaraan pemilukada adalah netralitas PNS. Dengan demikian, netralitas PNS diharapkan menjadi garda terdepan mengawal proses demokrasi lokal sehingga netralitas PNS ini dapat mengatasi kepentingan politik di daerah serta dengan hak politiknya dapat menentukan arah kepemimpinan daerah dengan tepat. ${ }^{23}$ Logika hubungan antara perintah dan larangan ikut serta dalam kepentingan politik memberikan sebuah makna substansial bahwa pada hakikatnya, setiap PNS diberikan perintah oleh negara untuk memberikan pelayanan kepada masyarakat secara profesional, jujur, adil, dan merata dalam penyelenggaraan tugas negara, pemerintahan dan pembangunan.

Bawaslu Provinsi Jawa Tengah sebagai salah satu lembaga penyelenggara pemilu lebih mengutamakan langkah-langkah preventif/pencegahan terhadap semua potensi pelanggaran, termasuk salah satunya pelanggaran netralitas PNS guna mengejawantahkan kebijakan yang berlaku. Selama ini, upaya Bawaslu Provinsi Jawa Tengah dalam mencegah potensi pelanggaran netralitas PNS dalam pemilukada lebih mengutamakan komunikasi dengan Satuan Kerja Perangkat Daerah (SKPD) masingmasing serta mensosialisasikan pentingnya netralitas PNS dalam menyukseskan penyelenggaraan pemilukada. Selain itu, Bawaslu Provinsi Jawa Tengah berdasarkan Undang-Undang No. 15 Tahun 2011 tentang Penyelenggara Pemilu, telah diberikan kewenangan untuk menindak semua pelanggaran yang terjadi khususnya

21 Wawancara dengan Komisioner Bawaslu Provinsi Jawa Tengah pada hari Senin 15 April 2014, pukul 10.30 WIB.

22 Wawancara dengan Bambang Kono, Kepala BKD Semarang pada hari Senin 15 April 2014, pukul 14.30 WIB.

23 Wawancara dengan Heru Tri Cahyono, S.Sos, Komisoner Panwaskab Purbalingga pada hari Kamis 15 Mei 2014 pukul 13.30 WIB. 
pelanggaran netralitas PNS. Apabila terindikasi adanya pelanggaran netralitas PNS dalam pemilukada, Bawaslu Provinsi Jawa Tengah akan mengacu pada aturan hukum tentang netralitas PNS dalam pemilukada seperti Undang-Undang No.32 Tahun 2004 tentang Pemerintahan Daerah, UU ASN, Peraturan Pemerintah No.53 Tahun 2010 tentang Disiplin PNS, serta aturan lain yang menyangkut netralitas PNS.

Senada dengan pernyataan Bawaslu Provinsi Jawa Tengah, Komisi Pemilihan Umum (KPU) Kabupaten Banyumas menjelaskan bahwa: ${ }^{24}$

1. KPU melaksanakan wewenang, tugas, dan kewajibannya berdasarkan peraturan perundang-undangan yang berlaku, termasuk di dalamnya hal-hal yang berkaitan dengan pengaturan netralitas PNS. Ketaatan kepada peraturan perundangundangan yang berlaku selalu diutamakan oleh KPU Kabupaten Banyumas dalam seluruh rangkaian tahapan pemilukada;

2. KPU Kabupaten Banyuma sebagai penyelenggara pemilu (termasuk pemilukada) yang bertugas melaksanakan pemilu di Kabupaten Banyumas, melaksanakan tugasnya berdasarkan peraturan perundang-undangan, keputusan, dan arahan dari KPU Pusat, sehingga ia tidak berwenang untuk membuat regulasi sendiri karena semua ketentuan yang berkaitan dengan pelaksanaan pemilukada sudah diatur secara rinci dan ketat oleh peraturan perundang-undangan dan regulasi yang dikeluarkan KPU Pusat;

3. Masalah netralitas PNS dalam Pemilukada Kabupaten Banyumas hanyalah salah satu permasalahan yang terjadi. Hal tersebut penting dan serius untuk diperhatikan, tetapi bukan merupakan fokus utama dari suatu penyelenggaraan pemilukada. Dalam pemilukada di Kabupaten Banyumas tidak ada regulasi maupun kebijakan khusus mengenai netralitas PNS, mengingat pengaturan dan kebijakan tentang netralitas PNS sudah secara lengkap dan jelas diatur dalam berbagai peraturan perundang-undangan terkait dan juga berbagai regulasi dan kebijakan yang dikeluarkan oleh KPU Pusat.

4. Berdasarkan peraturan perundang-undangan dan regulasi $\mathrm{KPU}$, dalam rangka menegakkan netralitas PNS dan menindak pelanggaran terhadap ketentuan netralitas PNS, maka penyelesaiannya dikembalikan kepada peraturan perundang-undangan yang berlaku dan penanganannya diserahkan kepada pejabat yang berwenang;

5. KPU Kabupaten Banyumas akan senantiasa memproses dan menindaklanjuti segala bentuk pelanggaran, termasuk pelanggaran terhadap ketentuan netralitas PNS.

24 Wawancara dengan Komisi Pemilihan Umum Banyumas pada hari Senin 16 Juni 2014, pukul 10.00 WIB. 
Mencermati konstruksi hukum atas netralitas PNS, maka kriteria yang digunakan untuk menentukan adanya unsur pelanggaran netralitas PNS dalam pemilukada antara lain:

1. Ikut serta sebagai pelaksana kampanye;

2. Menjadi peserta kampanye dengan menggunakan atribut partai/PNS;

3. Sebagai peserta kampanye dengan mengerahkan PNS di lingkungan kerjanya;

4. Sebagai peserta kampanye dengan menggunakan fasilitas negara;

5. Membuat keputusan dan/atau tindakan yang menguntungkan atau merugikan salah satu calon pasangan selama masa kampanye;

6. Mengadakan kegiatan yang mengarah kepada keberpihakan terhadap calon pasangan yang menjadi peserta pemilu sebelum, selama, dan sesudah masa kampanye yang meliputi pertemuan, ajakan, himbauan, seruan dan pemberian barang kepada PNS dalam lingkungan kerjanya, anggota keluarga, dan masyarakat;

7. Menjadi anggota Panitia Pemilihan Kecamatan (PPK), Panitia Pemungutan Suara (PPS), dan Kelompok Penyelenggara Pemungutan Suara (KPPS) dalam kegiatan pemilu tanpa izin dari atasan langsung.

\section{Faktor-faktor yang Memengaruhi Pelanggaran Netralitas Pegawai Negeri Sipil pada saat Pelaksanaan Pemilukada di Wilayah Jawa Tengah}

Berdasarkan hasil wawancara dengan Bawaslu Provinsi Jawa Tengah, Panwaskab Banyumas, Purbalingga, Solo, Karanganyar, Semarang, BKD Banyumas, Purbalingga, Solo, Karanganyar dan Semarang, dapat ditarik kesimpulan sementara bahwa netralitas PNS merupakan kebijakan bagi setiap PNS untuk melindungi diri dari masalah politik daerah dalam penyelenggaraan pemilukada. Selain itu, kebijakan netralitas bagi PNS juga diharapkan akan melindungi setiap PNS dalam perjalanan karirnya sebagai PNS.

Dalam implementasinya, terdapat masalah terkait ketidakjelasan makna yang dapat berimplikasi pada beragamnya tafsiran mengenai makna netralitas. Pada dasarnya, kata "netral" dari pengaruh semua golongan dan partai politik diartikan bahwa PNS tidak boleh menempatkan diri pada posisi golongan dan atau partai politik tertentu. Konsekuensinya adalah jika terdapat suatu kondisi PNS terpengaruh oleh situasi politik yang menguntungkan mereka, maka secara otomatis sikap netral dari PNS tersebut akan hilang. Pemaknaan ganda ini disampaikan oleh Kepala BKD Kota Semarang yang menyatakan bahwa kebijakan netralitas belum dapat dilaksanakan secara optimal karena persinggungan kepentingan politik dengan administrasi pemerintahan belum dapat dihilangkan. Hal tersebut dikarenakan kepala daerah sebagai pejabat pembina kepegawaian memiliki kewenangan dalam menentukan kebijakan kepegawaian terhadap PNS daerah sehingga dapat 
Sri Hartini, Setiajeng Kadarsih, dan Tedi Sudrajat: Kebijakan Netralitas Politik Pegawai Negeri Sipil dalam Pemilukada (Studi di Jawa Tengah)

melakukan intervensi terhadap PNS di bawahnya. Selain itu, netralitas belum dapat dijalankan sepenuhnya seperti yang diharapkan karena hak politis PNS masih ada. ${ }^{25}$

Berdasarkan wawancara dengan Kepala Bidang (Kabid) Pengangkatan dan Pengembangan BKD Karanganyar, dijelaskan bahwa PNS dapat mencalonkan diri menjadi calon kepala/wakil kepala daerah dan hal tersebut tidak mempengaruhi netralitas PNS karena batasan netralitas adalah tidak menjadi anggota dan pengurus partai politik. Jika ada partai yang mengusung calon kepala daerah dari PNS mereka, masih diperbolehkan diberhentikan sementara dari jabatan negerinya selama mereka mencalonkan diri. ${ }^{26}$ Adapun dalam pelaksanaan kegiatan politik, PNS masih diperbolehkan menjadi peserta kampanye. Berdasarkan wawancara dengan Kabid Data dan Pembinaan Pegawai BKD Purbalingga, dijelaskan bahwa PNS dapat menjadi peserta kampanye sepanjang tidak menggunakan atribut kedinasan dan tidak menggunakan fasilitas dinas. ${ }^{27}$

Hal tersebut mengindikasikan bahwa pemerintah masih kesulitan dalam menempatkan makna netral dari pengaruh politik dan golongan tertentu. Apabila PNS ikut menjadi peserta kampanye, jelas PNS tersebut memosisikan diri menjadi tidak netral, terlebih lagi ketika dia memberikan hak pilihnya. Pernyataan ini memberikan makna bahwa terdapat aturan yang menimbulkan celah hukum yang dapat digunakan oleh PNS untuk berperan aktif dalam proses politik. Hal ini disebabkan oleh aturan yang berlaku kurang tegas (limitatif) dan sehingga menimbulkan kerancuan atau pertentangan interpretasi.

Makna diatas menciptakan pemahaman bahwa netralitas seolah-olah menciptakan standar ganda terhadap kedudukan PNS, baik secara individu maupun institusi. Hal ini sangat dimaklumi tatkala netralitas yang dimaksud masih menciptakan pemahaman yang beragam (ambigu). Artinya ranah politik bukanlah hal yang netral karena setiap PNS masih diberikan hak untuk memilih dan dipilih dalam konteks politik. Dalam tataran realitas, standar ganda tersebut semakin diperkeruh dengan banyaknya kasus yang bersinggungan dengan keterlibatan dari PNS dalam kegiatan politik di Indonesia.

Secara normatif, prosedur penanganan pelanggaran netralitas PNS yang pada didasarkan pada Perbawaslu No. 2 Tahun 2012 tentang Tata Cara Pelaporan dan Penanganan Pelanggaran Pemilihan Umum Kepala Daerah dan Wakil Kepala Daerah adalah:

25 Wawancara dengan Bambang Kono, Kepala BKD Kota Semarang pada hari Senin 15 April 2014, pukul 14.30 WIB.

26 Wawancara dengan Suranto, Kepala Bidang Pengangkatan dan Pengembangan BKD Karanganyar pada hari Rabu 18Juni 2014, pukul 10.00 WIB.

27 Wawancara dengan Ardi Pawoko, Kabid Data dan Pembinaan Pegawai BKD Purbalingga pada hari Kamis 15 Mei 2014, pukul 09.00 WIB. 
1. Penanganan pelanggaran pemilukada oleh Bawaslu Provinsi Jawa Tengah dapat berasal dari laporan masyarakat maupun temuan dari pengawas pemilu.

2. Laporan atau temuan pelanggaran disampaikan kepada pengawas pemilukada paling lambat 7 hari sejak terjadinya pelanggaran.Terkait pelanggaran netralitas PNS dalam penyelenggaraan pemilukada, mekanisme penanganannya juga didasarkan pada Perbawaslu No. 2 Tahun 2012.

3. Setelah menerima laporan atau menemukan adanya dugaan pelanggaran netralitas PNS dalam penyelenggaraan pemilukada, Bawaslu Provinsi Jawa Tengah mengkaji dan memutuskan paling lama 14 hari setelah laporan pelanggaran diterima atau ditemukan.

4. Jika dugaan pelanggaran netralitas PNS berdasarkan kajian Bawaslu Provinsi Jawa Tengah merupakan tindak pidana, maka akan diteruskan ke kepolisian.

5. Jika dugaan pelanggaran netralitas PNS yang merupakan pelanggaran administrasi, maka akan direkomendasikan kepada BKD/Kepala Daerah dan Wakil Kepala Daerah terkait untuk memberikan sanksi administrasi berdasarkan peraturan perundang-undangan kepada PNS yang bersangkutan.

Setidaknya terdapat dua bentuk pelanggaran yang potensial dilakukan oleh PNS, yaitu:

1. Pelanggaran tindak pidana: pelanggaran tindak pidana adalah serangkaian tindak pidana yang diatur secara khusus dalam perundang-undangan yang mengatur tentang pemilukada;

2. Pelanggaran administrasi: pelanggaran administrasi adalah pelanggaran terhadap ketentuan undang-undang terkait pemilu yang tidak termasuk dalam ketentuan pidana pemilukada dan ketentuan lain yang diatur dalam Peraturan KPU.

Berdasarkan pengalaman penyelenggaraan Pemilukada Jawa Tengah Tahun 2013, terdapat satu bentuk pelanggaran tindak pidana yang dilakukan oleh PNS Pemerintah Kabupaten Magelang. PNS tersebut didakwa dengan Pasal 116 ayat (3) Undang-Undang No. 32 Tahun 2004 tentang Pemerintahan Daerah serta telah divonis oleh Pengadilan Negeri Kabupaten Magelang dengan pidana denda sejumlah Rp1.000.000,00 dengan ketentuan apabila denda tersebut tidak dibayar; hukuman diganti dengan dua bulan kurungan.

Walaupun secara normatif telah dijelaskan secara detail, namun dalam tataran teknis belum ada kejelasan mengenai prosedur pelimpahan kewenangan. Hal ini disampaikan BKD Kabupaten Purbalingga bahwa fungsi koordinasi antar lembaga belum berjalan, baik dari BKD, Inspektorat, Panwaslu, dan Pejabat Pembina Kepegawaian Daerah. Berdasarkan informasi dari Panwaskab Purbalingga, diketahui bahwa banyak kasus yang ditutup atau tidak dapat dibuktikan karena lemahnya fungsi koordinasi dan tidak adanya kejelasan kelembagaan yang memproses 
Sri Hartini, Setiajeng Kadarsih, dan Tedi Sudrajat: Kebijakan Netralitas Politik Pegawai Negeri Sipil dalam Pemilukada (Studi di Jawa Tengah)

pelanggaran. Biasanya, hasil temuan pelanggaran langsung direkomendasikan ke kepala daerah selaku pejabat pembina kepegawaian, namun kemudian tidak ditindaklanjuti. Lain halnya dengan Kabupaten Karanganyar, pemerintah daerahnya melakukan sosialisasi mulai dari birokrasi terendah secara berjenjang dan dalam proses sosialisasinya digunakan media langsung (penyuluhan) ke SKPD dan radio untuk masyarakat. Hal ini memberikan gambaran bahwa terdapat praktik yang baik di daerah guna mengantisipasi terjadinya pelanggaran, namun terdapat juga pembiaran terhadap masalah pelanggaran netralitas di daerah karena tidak jelasnya fungsi pengawasan dan koordinasi antar lembaga. Pernyataan di atas memberikan makna bahwa faktor kelembagaan dalam penanganan pelanggaran netralitas masih belum secara jelas diatur, sehingga ada kecenderungan antar lembaga saling melepaskan tanggungjawab jika terdapat pelanggaran.

Adapun analisis dari faktor masyarakat dan internal PNS sebagai bagian dari masyarakat, berdasarkan kajian dari Bawaslu, dapat diketahui bahwa faktor yang memengaruhi terjadinya pelanggaran terhadap netralitas PNS meliputi:

1. Ikatan-ikatan primordial dalam masyarakat Indonesia masih sangat kental. Hal ini sangat berpengaruh dalam penentuan sikap politik seorang PNS. Jika seorang PNS mempunyai saudara, famili, atau keluarga yang dituakan yang terlibat dalam politik praktis, dalam masyarakat yang primordial tentunya mereka tidak akan membiarkan saudaranya berjuang sendiri dalam mencapai tujuannya.

2. Kepala daerah adalah Pembina PNS di daerah. Seorang kepala daerah yang dipilih melalui proses politik tentunya dituntut untuk selalu memperkuat basis politiknya agar dapat bertahan. Dalam kondisi ini, seorang kepala daerah akan berupaya untuk memanfaatkan semua sumber daya yang ada untuk tetap dapat mempertahankan kekuatan politiknya, termasuk terhadap PNS yang berada di bawah kekuasaannya.

3. Pengalaman pribadi para PNS dalam proses pemilukada. Pengalaman ini merekam bahwa siapa saja yang berjasa dalam proses pemilukada akan berkesempatan untuk mendapat promosi sebagai imbalan atas jasanya. ${ }^{28}$ Pilihan

28 Cermati substansi Peraturan Pemerintah No. 9 Tahun 2003 tentang Wewenang Pengangkatan, Pemindahan dan Pemberhentian PNS. Secara normatif, sikap PNS yang tidak netral dipicu oleh ambiguitas regulasi di dalam aspek hukumnya. Pada satu sisi PNS diharapkan bersikap profesional dan netral, akan tetapi dalam penjenjangan kariernya sangat ditentukan oleh Pejabat Pembina Pegawai Negeri Sipil, dalam hal ini adalah gubernur, bupati atau walikota yang notabene merupakan kepala daerah sebagai pejabat politik yang dipilih melalui mekanisme politik. Oleh karena itulah, ketika kepala daerah terpilih dari partai politik yang memiliki kekuasaan yang sangat kuat (powerful authority), maka berdasarkan kewenangan administratif kepegawaian yang dimilikinya dapat memberikan penghargaan (reward) terhadap pihak yang membantunya dalam mencapai kekuasaan. Akibatnya, birokrat yang menjalankan prinsip netral (netralitas) biasanya menjadi korban dan dimutasi ke tempat-tempat yang tidak mereka kuasai bidangnya, sedangkan mereka yang aktif berpolitik dan menjadi tim sukses terselubung (PNS) akan menuai banyak keuntungan setelah terpilih sebagai kepala daerah. 
bagi PNS selanjutnya adalah menjadi penonton dalam proses politik; menjadi penonton dalam promosi; atau terlibat dalam politik praktis dengan risiko promosi bila menang atau emosi bila kalah. ${ }^{29}$

Berdasarkan penjabaran di atas, setiap manusia (termasuk birokrat publik) mempunyai peranan tertentu dan hak untuk berperan serta dalam politik yang dilindungi oleh hukum. Makna yang terkandung adalah birokrat pemerintah tidak dapat dilepaskan dari proses dan kegiatan politik. Pada setiap gugusan masyarakat modern yang membentuk suatu tata pemerintahan, terdapat aspek politik. Politik sebagaimana diketahui terdiri dari orang-orang yang berperilaku dan bertindak politik (consists of people acting politically), yang diorganisasikan secara politik oleh kelompok-kelompok kepentingan serta mencoba memengaruhi pemerintah untuk mengambil dan melaksanakan suatu kebijakan dan tindakan yang dapat mengangkat kepentingannya yang kemudian menyampingkan kepentingan kelompok lainnya.

\section{Penutup}

Politik hukum pemerintah terhadap kedudukan PNS berubah-ubah sejak tahun 1945 sampai dengan saat ini. Hal ini memberikan makna bahwa kedudukan PNS telah menjadi bagian penting dalam struktur pemerintahan. Salah satu tuntutan akan perubahan kedudukan dari PNS adalah pembatasan dalam ranah politik yang secara normatif diistilahkan dengan netralitas. Hingga saat ini, PNS sebagai bagian dari ASN masih diberikan hak pilih dalam pemilu namun dibatasi dalam hal keikutsertaannya dalam politik praktis.

Adapun kriteria yang digunakan untuk menentukan adanya unsur pelanggaran netralitas PNS dalam Pemilukada yaitu:

a. Ikut serta sebagai pelaksana kampanye;

b. Menjadi peserta kampanye dengan menggunakan atribut partai/PNS;

c. Sebagai peserta kampanye dengan mengerahkan PNS di lingkungan kerjanya;

d. Sebagai peserta kampanye dengan menggunakan fasilitas negara;

e. Membuat keputusan dan/atau tindakan yang menguntungkan atau merugikan salah satu calon pasangan selama masa kampanye;

f. Mengadakan kegiatan yang mengarah kepada keberpihakan terhadap calon pasangan yang menjadi peserta pemilu sebelum, selama, sesudah masa kampanye yang meliputi pertemuan, ajakan, himbauan, seruan dan pemberian barang kepada PNS dalam lingkungan kerjanya, anggota keluarga dan masyarakat;

g. Menjadi anggota Panitia Pemilihan Kecamatan (PPK), Panitia Pemungutan Suara 
Sri Hartini, Setiajeng Kadarsih, dan Tedi Sudrajat: Kebijakan Netralitas Politik Pegawai Negeri Sipil dalam Pemilukada (Studi di Jawa Tengah)

(PPS), dan Kelompok Penyelenggara Pemungutan Suara (KPPS) dalam kegiatan pemilu tanpa izin dari atasan langsung.

Faktor yang memengaruhi terjadinya pelanggaran diantaranya:

a. Faktor aturan yang menimbulkan celah hukum sehingga dapat digunakan oleh PNS untuk berperan aktif dalam proses politik. Hal ini disebabkan oleh aturan yang berlaku kurang tegas (limitatif) sehingga menimbulkan kerancuan atau pertentangan interpretasi. Contohnya diperbolehkannya PNS menjadi peserta kampanye dan memiliki hak pilih. Dua hal tersebut mengindikasikan bahwa pemerintah masih kesulitan dalam menempatkan makna netral dari pengaruh politik dan golongan tertentu. Apabila PNS ikut menjadi peserta kampanye, maka jelas PNS tersebut memosisikan diri menjadi tidak netral, terlebih lagi ketika dia memberikan hak pilihnya;

b. Faktor internal yang memengaruhi terjadinya pelanggaran terhadap netralitas PNS adalah keinginan setiap PNS untuk mendapatkan karier di pemerintahan daerah dengan cara memberikan dukungan, baik secara langsung maupun tidak langsung, terhadap pasangan calon tertentu. Hal tersebut akan memengaruhi perjalanan karier PNS tersebut. Selain itu, netralitas PNS juga dipengaruhi oleh hubungan kekerabatan (keluarga) PNS tertentu dengan salah satu pasangan calon yang maju dalam pemilukada atau pasangan calon yang maju dalam pemilukada berasal dari pimpinan PNS di SKPD atau instansi pemerintahan daerah tersebut;

c. Faktor kelembagaan dalam penanganan pelanggaran netralitas masih belum secara jelas diatur, sehingga ada kecenderungan antar lembaga saling melepaskan tanggungjawab jika terdapat pelanggaran;

d. Faktor masyarakat yang cenderung membiarkan (permisif) jika terjadi pelanggaran sehingga banyak kasus pelanggaran netralitas PNS tidak dapat tertangani oleh penegak hukum.

Ketegasan dari pemerintah tentang eksistensi dari birokrat publik, khususnya PNS terhadap hak politiknya sangat diperlukan. Pada dasarnya, pilihannya hanya dua yaitu dilarang untuk terlibat dalam segala bentuk aktivitas politik atau diberikan kebebasan seperti halnya masyarakat umum demi menegakkan prinsip kesetaraan dan kesederajatan hak politik.

a. Jika pemerintah mengambil opsi pelarangan, maka hal yang perlu diperhatikan adalah merasionalisasikan pelarangan tersebut dalam bentuk produk peraturan perundang-undangan (secara hierarkis) dan pemerintah harus membuktikan bahwa pelarangan tersebut dilakukan semata untuk menjamin pengakuan serta penghormatan atas hak dan kebebasan orang lain serta memenuhi tuntutan yang adil sesuai dengan pertimbangan moral, keamanan, dan ketertiban umum dalam suatu masyarakat demokratis; 
b. Jika pemerintah mengambil opsi pembebasan, maka perlu adanya perubahan tatanan hukum, pembentukan mekanisme pengawasan dan penegakan hukum yang dapat menciptakan kinerja yang profesional dalam diri birokrat publik. Pada satu sisi, pembatasan memiliki tujuan yang baik, namun di sisi lain, pembatasan dapat merugikan dan menghilangkan hak politik PNS. PNS tidak dapat berperan aktif dalam aktivitas politik secara bebas dan karenanya tidak ada unsur PNS di DPR. Berkaitan dengan hal tersebut, pengaturan tentang hak, kewajiban dan kesejahteraan PNS akan ditentukan oleh belas kasihan anggota DPR. Alasan yang demikian ini seharusnya dinilai berlebihan, sebab dengan situasi dan kondisi masyarakat yang sudah demikian terbuka, maka tidak cukup menjadi alasan untuk membenarkan pembatasan hak-hak politik PNS.

Apabila kedua opsi yang ditawarkan maka masih dianggap sulit untuk direalisasikan, maka Penulis memberikan solusi alternatif yang dapat meminimalkan pelanggaran yang dilakukan oleh PNS yaitu:

a. Terdapat celah hukum bagi PNS yang berminat menjadi kepala daerah dengan cara melepaskan jabatan PNSnya pada saat diusung menjadi calon kepala daerah. Jika ia tidak terpilih maka ia dapat kembali menjadi PNS. Sebaliknya, setelah selesai melaksanakan jabatannya, maka ia dapat kembali menjadi PNS setelah selesai melaksanakan jabatannya. Meskipun jelas apabila ia diusung menjadi calon kepala daerah, maka ranah politik praktis sudah menghilangkan esensi dari netralitas;

b. Perubahan pengaturan terhadap Pejabat Pembina Kepegawaian Daerah yang memiliki kewenangan untuk menetapkan pengangkatan, pemindahan dan pemberhentian PNS yang dilimpahkan kepada Sekretaris Daerah. Hal ini dimaksudkan agar tidak terjadi ambiguitas regulasi. Kepala daerah adalah pejabat politis yang tidak dapat melakukan intervensi terhadap kebijakan kepegawaian yang akan berpengaruh pada kedudukan dari PNS;

Untuk memperkuat struktur kelembagaan dalam penanganan pelanggaran netralitas, perlu dibuat suatu hubungan kerja fungsional-struktural dari Bawaslu, Panwaslu, BKD dan Inspektorat di masing-masing daerah. Penulis berpendapat bahwa:

a. Lembaga yang menentukan jenis pelanggaran adalah BKD, dan Inspektorat;

b. Lembaga yang merekomendasikan pelanggaran yang telah dilakukan oleh oknum PNS adalah Panwaslu;

c. Lembaga yang menetapkan pelanggaran yang dilakukan oleh oknum PNS adalah Panwaslu, BKD, dan Inspektorat;

d. Lembaga yang memberikan sanksi adalah walikota/bupati/gubernur.

Selain struktur kelembagaan, diperlukan juga Standar Operasional Prosedur (SOP) guna memperjelas kewenangan dari masing-masing lembaga tersebut sehingga ada kejelasan dalam penegakan sanksinya. 
Sri Hartini, Setiajeng Kadarsih, dan Tedi Sudrajat: Kebijakan Netralitas Politik Pegawai Negeri Sipil dalam Pemilukada (Studi di Jawa Tengah)

\section{Daftar Pustaka}

\section{Buku}

Afan Gaffar, Politik Indonesia Transisi Menuju Demokrasi, Pustaka Pelajar, Yogyakarta, 1999.

Ellydar Chaidir, Sistem Pemerintahan Negara Republik Indonesia Pasca Perubahan Undang-Undang Dasar 1945, Total Media, Yogyakarta, 2008.

Korpri DKI Jakarta, Korpri dan Perkembangannya, Korpri, Jakarta, 1988.

Mahfud M.D., Pergulatan Politik dan Hukum di Indonesia, Gama Media, Yogyakarta, 1999.

Miftah Thoha, Birokrasi dan Politik di Indonesia, Raja Grafindo Persada, Jakarta, 2007.

Mifta Thoha, Birokrasi Pemerintah Indonesia di Era Reformasi, Prenada Media Group, Jakarta, 2008.

Mohtar Mas'oed, Politik, Birokrasi dan Pembangunan, Pustaka Pelajar, Yogyakarta, 2008.

Philipus M.Hadjon (et.al.), Pengantar Hukum Administrasi Indonesia, Gadjah Mada University Press, Yogyakarta, 2005.

S.F. Marbun dan Mahfud M. D., Pokok-Pokok Hukum Administrasi Negara, Liberty, Yogyakarta, 1987.

Soerjono Soekanto, Kesadaran Hukum dan Kepatuhan Hukum, Rajawali, Jakarta, 1982.

YKPI, Peranan dan Tugas Pegawai Republik Indonesia dalam Pembangunan, Jakarta, 1984. 